\title{
Legitimacy and Forced Democratisation in Social
} Movements

A Case Study of the Umbrella Movement in Hong Kong

\section{Chi Kwok and Ngai Keung Chan}

\section{OpenEdition}

\section{Journals}

Electronic version

URL: http://journals.openedition.org/chinaperspectives/7375

ISSN: 1996-4617

\section{Publisher}

Centre d'étude français sur la Chine contemporaine

\section{Printed version}

Date of publication: 1 September 2017

Number of pages: 7-16

ISSN: 2070-3449

\section{Electronic reference}

Chi Kwok and Ngai Keung Chan, « Legitimacy and Forced Democratisation in Social Movements »,

China Perspectives [Online], 2017/3 | 2017, Online since 01 September 2017, connection on 28 October 2019. URL : http://journals.openedition.org/chinaperspectives/7375 


\title{
Legitimacy and Forced
}

\section{Democratisation in Social}

\section{Movements}

\author{
A Case Study of the Umbrella Movement in Hong Kong
}

\section{CHI KWOK AND NGAI KEUNG CHAN}

\begin{abstract}
Social movements are voluntary events whose participants have the right to leave whenever they disagree with their leaders. For this reason, the legitimacy of social movements is often perceived as inherent and thus of only secondary importance. This article aims to repudiate this view by demonstrating that legitimacy issues can impose constraints and have significant impacts on the relationships and decisions of the leaders of social movements. In the case of the Umbrella Movement, bottom-up legitimacy challenges to movement leaders' authority not only forced the leaders to reform their decision-making structure and even implement direct democracy, but also intensified the relationships among the leaders of different factions, ultimately undermining the leadership's overall effectiveness.
\end{abstract}

KEYWORDS: Legitimacy, Forced Democratisation, Social Movement, Umbrella Movement, Hong Kong.

\section{Introduction}

T he conventional view on legitimacy emerges from discussions on political authority and is primarily concerned with coercive relationships. Although this perspective has also dealt with non-coercive organisations, it focuses more on the interplay between organisation survival and legitimacy than on the cooperative efforts and difficulties of maintaining legitimacy in inclusive movements comprising multiple organisations. The moderate view believes that the legitimacy of social movements derives from pure intentions and positive consequences, rather than democratic procedures. Based on interviews of leaders of major groups within the Umbrella Movement (UM), this article argues that the absence of effective democratic procedures might lead to what we call the "forced democratisation" of decision-making power: a bottom-up challenge of the legitimacy of the decision-making group's interest representation. This article has two purposes: (1) to argue that even in apparently voluntary social movements, such as the UM, legitimation is still a significant concern for participants, and (2) to demonstrate that legitimation crises can constrain leaders' choice of strategic options, hence altering the course of the movement.

We first discuss the significance of legitimacy as a conceptual tool in explaining social movements. Then, after discussing our research method and context, we articulate how legitimacy concerns have affected UM leaders' major decisions and respective legitimating mechanisms. Finally, we discuss the implications of the findings.

\section{Leadership legitimation}

Social movements are voluntary events: participants can quit whenever they want, and there is no coercive relationship between participants and leaders. The chief concern for social movement leaders is to mobilize social movement bases by building a consensus among organisational networks and potential participants (Tilly and Tarrow 2015). The choice by several movement organisations to include the word "consent" in their founding documents and guidelines may create the illusion that the issue of legitimacy is settled prior to the beginning of a movement (Earl 2007; Porta 2009). However, as James Q. Wilson (1974) accurately depicts, coordinating actions in voluntary associations can be challenging:

In most voluntary associations, authority is uncertain and leadership is precarious. Because the association is voluntary, its chief officer has neither the effective power nor the acknowledged right to coerce the members - they are, after all, members and not employees. (p. 215)

People do challenge the legitimacy of leaders, and negotiations of interests among participants are an important component of collective actions. Sometimes, people feel that leaders have organisational advantages that they lack; hence, they are reliant on their leaders for claim-makings. Yet, leaders might be inefficient in communicating with participants about their concerns, or they might reach unfair or biased decisions (Michels 1962). 
Leadership in large-scale movements is always uncertain and precarious because dynamics and conflicts among participants are complicated and unavoidable (Cheng and Chan 2017). Scholars are not unaware of the issue of legitimation (e.g., Haunss 2007), and some recent research has attempted to examine the ways in which social movements can gain legitimacy in the eyes of the public (Andrews, Beyerlein, and Tucker 2015). In later sections, we will discuss how leaders might try to resolve legitimacy crises within a movement by appealing to public legitimacy.

Zald and Ash (1966, p. 335) argued that an important reason that a movement organisation may fail is its "inability to maintain legitimacy even in the eyes of its supporters." Legitimacy problems emerge when marginal organisations within the same social movement industry attempt to differentiate their tactics and visions from those of major organisations, since attacking one another's legitimacy can be useful in the competition for resources (Zald and McCarthy 1980, pp. 5-10; Soule and King 2008). Snow and Benford (1992, p. 150) pointed out that a legitimacy problem might appear when a "master frame" connecting different participants is challenged by competing frames. In other words, leaders "can mobilize legitimacy $[. .$.$] only when they are able to frame the grievances and interests of$ aggrieved constituencies [...] provide solutions, and enable collective attribution processes to operate" (Rao, Morrill, and Zald 2000, p. 242). Legitimacy is important for the survival of an organisation and a movement, but it is unclear how or in what way legitimacy concerns affect leadership and thus the movement. In studies of the impact of leadership dynamics on movement outcomes, the agential view suggests that types of leadership are independent variables that significantly shape the outcomes of movements, whereas the "contingency view," while recognising the crucial role of leaders, sees leaders as "essentially servants of their followers" (Aminzade, Goldstone, and Perry 2001, p. 127; Dinh et al. 2014). These perspectives provide illuminating insights into whether and how leaders can influence movements; yet, leaders' agency is also heavily influenced by whether a legitimacy problem is settled. Our view resembles that of Snow and Benford (1992) in that we see leaders as "acting as intermediaries": they mobilise the public and make strategic decisions, but do not do so as they please (Aminzade et al. 2001, p. 127). Advancing this literature, the present article aims to show: (1) how the legitimation problem can be an independent and significant factor that shapes the course and outcomes of a large-scale movement, even when major actors have predicted the problem and actively sought solutions prior to the beginning of the movement; (2) that legitimation challenges from participants can confine leaders' agency and direct their attention toward internal conflicts; and (3) the actual process through which these dynamics play out.

Leaders are critical to social movements. They perform significant tasks that are necessary for sustained campaigns of collective claim-making (McAdam, Tarrow, and Tilly 2001; Tarrow 2011, p. 12), including articulating ideology, engaging the public, making strategic and tactical decisions, and so on (Cai 2017, p. 4; Earl 2007; Ganz 2010; Morris and Staggenborg 2004). Their legitimacy is crucial to the effective coordination of collective claimmaking because it requires the cooperation and obedience of participants. There are four primary approaches of legitimation, by which we mean the types of legitimacy claims that leaders make to gain authority over voluntary participants.

Weberian Charismatic Approach: A dominant approach to understanding leadership legitimation is the "Weberian" charismatic approach. Weber's (1947) three conceptions of authority - legal, traditional, and charismatic
- are useful tools for conceptualising leadership legitimacy (Morris and Staggenborg 2004; Platt and Lilley 1994). This approach explains leaders' legitimacy based on their charismatic personality, purity, and credibility. ${ }^{(1)}$ Functional Approach: Robert Michels' (1962) work provides an organisational perspective that elucidates the legitimation process. Large movements require large organisations. Large organisations cannot avoid hierarchy, and hierarchy requires people who are capable of carrying out necessary tasks. Thus, leaders' legitimacy is justified by their functional necessity (i.e., their successful completion of coordinating tasks) in the hierarchy (Michels 1962; Morris and Staggenborg 2004). (2)

Consensual Approach: The democratic nature of civil society increases demands to respect every participant in the decision-making process. The result is the widespread use of the consensual decision-making model in social movements (Kaldor 2003; Mansbridge 2003; Tarrow 2011, p. 11; Wapner 1995, p. 313). Nevertheless, consensus can be achieved through various means other than democratic voting, such as surveying and incorporating ground-level opinions into the decision-making process, forming deliberative fora among major groups, etc.

Democratic Approach: Once a legitimacy crisis emerges, leaders can utilise fair democratic voting to resolve disputes and conflicts (Toepfl 2017). ${ }^{(3)}$

Theoretically, these four mechanisms can be distinguished from one another; however, in practice, leaders often employ more than one single mechanism to legitimise the decision-making hierarchy. While a specific legitimating mechanism might be able to resolve several legitimacy problems at once, it would fail to achieve the same in other periods when participants come to demand more than what it can offer. Changes in legitimation requirements can significantly affect leaders' major decisions, since the decline of legitimacy often leads to demobilisation (Tilly and Tarrow 2015, pp. 97-98). The multiplicity and fluidity of legitimation mechanisms and the ways in which they interact with changing group conditions are important in explaining the growth or degeneration of a movement. The UM is a valuable case for exploring this topic because most of the major strategic choices that affected the course of the movement revolved around issues of legitimation.

\section{Research context}

The UM, which lasted for 79 days (from 28 September to 15 December 2014), was the largest social movement in Hong Kong's recent history. At first, the play was to host an occupying movement (called the "Occupy Central Movement" [OC]) in Central for a relatively short period of time;

1. In elaborating the Weberian charismatic leader, Aminzade, Goldstone, and Perry (2001) argued that charisma means the abilities and attributes of a person that make him capable of evoking "emotions that create a community of feeling" or revoking "emotions by creating affective dissidence that leads followers to rethink their worldviews." Therefore, we see purity as a kind of charisma because it leads participants to believe that a person is "working for a public good, rather than personal advantage," which can be an important condition for mobilising emotions and sympathy (Aminzade et al. 2001, pp. 129-130).

2. To clarify, a leader does not automatically become a legitimate leader simply because he is a leader. Instead, the functional approach emphasises that a leader can raise a claim to legitimacy based on the successful completion of important tasks attached to a leadership position. Participants' acceptance of such a claim will depend on many factors, but the most important of these (according to this approach) is whether the leader is the best person to fulfil the functional tasks of the position. We thank the anonymous reviewers for this point.

3. The democratic approach is very similar to Weber's rational-legal authority, since the latter highlights a bureaucracy's legally established "patterns of normative rules" as the sources of its legitimacy. Although these patterns are usually seen as the foundation of democracy, this is not necessarily the case. A major critique of Weber (1947, p. 328) is that such legal-rational authority did exist in Imperial China (Turner 2008). 
however, the movement unexpectedly grew into an occupying initiative spanning three sites (Admiralty, Causeway Bay, and Mongkok) after police officers fired 87 canisters of tear gas at the protesters (Tang 2015). The abrupt transformation from the $\mathrm{OC}$ to the UM raises three important questions: (1)Who were the leaders, and who were they representing? (2) How did the sudden change challenge leaders' legitimacy and affect their decisions? (3) What were the legitimating mechanisms being adopted by the leadership coalition, and how did they affect the movement? This article contributes to the extant literature by providing a more nuanced inquiry into the UM leadership's decision-making from the perspective of legitimacy. Below, we explicate several of the major themes identified in studies of the UM and explain our potential contributions.

The first line of UM research examines mobilisation in terms of the structural and historical contingencies of protests in Hong Kong. Identity politics is a major focus of this stream (Rühlig 2016, p. 62). Activists believe that the Beijing government has failed to fulfil its promise to implement universal suffrage (Davis 2015; Veg 2015), and Hong Kong's under-preparation for regional integration since 2009 has given rise to an anti-mainland sentiment (Lui 2015). The concentration of political power and economic capital in the hands of corporations and pro-establishment politicians has resulted in not only social inequality but also an accumulation of citizens' grievances against mainland China's influence and social inequality (Hui and Lau 2015; Ortman 2015). These studies situate the movement's mobilisation within Hong Kong's historical context and identity formation. In addition to identity politics, this stream of literature has highlighted the ways in which UM repertories were conditioned by antecedent events (Cheng 2016, p. 384). For example, the UM's discursive frames were shaped in part by "Tiananmen veterans" (e.g., "Occupy Central with Love and Peace"; hereafter OCLP) and their fear of violent crackdowns (Lagerkvist and Rühlig 2016). The OCLP's campaign of civil disobedience helped the occupation gain public legitimacy (Lee 2015). The "Anti-Moral and National Education Movement" organised by Scholarism in 2012 also cultivated anti-mainland Chinese government sentiments and provided the UM with tactical and discursive resources (Wang 2017). This literature provides precious insights into the structural conditions that enable and constrain the UM's mobilisation and protest tactics. Yet, as Cheng and Chan (2017, p. 224) argued, there is a need to further examine how and why the movement evolved over time through a focus on contingent events and their interactions with the existing structure. This article ties in with these insights by demonstrating how a series of legitimacy crises caused different legitimating mechanisms at specific points in time. More importantly, the article seeks to explain the internal constraints affecting the agency of movement leaders.

The second stream of literature has explored the spontaneous nature of the movement by looking at contingent events (Cheng and Chan 2017) and different UM groups' occupation practices. The spontaneity of the movement provided space for protesters to create personal action frames (Veg 2016), articulate a playful form of protest (Gan 2017), and conduct a "leaderless" movement (Lin and Liu 2016). However, leaders did exist, and they performed mobilisation and framing functions within the UM (Cai 2017, pp. 11-12; Cheng and Chan 2017, p. 223). Wong (2015) and Chan (2015) highlighted the intensification of inter-group conflicts throughout the UM, and Cheng and Chan (2017) found a lack of consensus concerning who was the legitimate leader. In general, however, these studies have not sufficiently accounted for how or why the movement's legitimacy transformed over time. One exception is Lee's (2016) study of the construction of public opin- ion in newspaper discourse. As he argued, public opinion might have affected the movement leaders' decisions, especially since "the images of a pro-retreat public constituted a consideration against escalating the action" (Lee 2016, p. 605). The present paper contributes to understanding how and why the UM leadership failed to sustain the movement's legitimacy over time. A third focal point in the literature is the "emergence of a new digital counterpublic sphere" (Rühlig 2016, p. 62). The rise of digital media enabled a crucial form of mobilisation in the UM - that is, a seemingly "leaderless" connective action (Lee, So, and Leung 2015) - by allowing individuals to circulate alternative information about the movement outside the traditional news media and to utilise their highly personalised digital networks for political mobilisation (Lee and Chan 2016). Protesters creatively articulated media practices to facilitate mobilisation (Lee and Ting 2015; Lin 2017), build identities, and express emotions (Rühlig 2016; Veg 2016). While this stream of literature shows that individuals participated in the UM in their own ways, the present article enhances the understanding of how both leaders and protestors played important roles that shaped the movement's course and outcomes by focusing on the leadership's attempt to account for protesters' highly personalised visions of the movement in their decision-making processes.

\section{Method and data}

This study utilised (1) semi-structured interviews with the major leaders of the UM, (2) materials available on relevant organisations' websites and Facebook pages, and (3) news coverage and commentary of the UM available on WiseNews.

We conducted six in-depth, semi-structured interviews with core activists from the OCLP, Hong Kong Federation of Students (HKFS), and key civil society organisations (CSOs) in 2015 and 2016. The interviewees were responsible for a variety of leadership works and roles within the UM, which are listed in Table 1. Three of the interviewees were core members of the leadership coalition and took part in the decision-making process; another three were "bridging leaders" who connected the leadership coalition with ordinary protesters (Robnett 1996); they performed "bridging tasks," such as disseminating messages from the leadership coalition to ground-level protesters. Of the three "bridging leaders," one was also responsible for coordinating pickets; the other two were responsible for day-to-day logistics support for the occupation sites. We asked the interviewees about their perspectives on the movement, the struggles they faced, and the rationales behind the decisions they made. Informed consent was acquired. To protect the interviewees' identities, each interviewee will be referred to in the present text by a speaker ID (P1 to P6). All interviews were conducted on campus at the Chinese University of Hong Kong, except for the interview with P6, which was conducted at the University of Hong Kong (HKU). Each interview lasted between 45 and 80 minutes. We also drew upon data from websites and Facebook pages for the OCLP, HKFS, and Scholarism to map the contexts of the various legitimating mechanisms. Relevant news coverage and commentary were derived from a keywords search (e.g., "leadership in the UM"). We utilised the news materials to identify the leadership coalitions' major decisions and potential dynamics. These data sources help to triangulate the findings (Maxwell 2013) and provide a richer picture of the UM.

We employ Sewell's (1996) event-centred approach to analyse the evolution of legitimating mechanisms within the UM. As Sewell (1996, p. 843) suggested, events are "sequences of occurrences that result in transformations of structures" instead of happenings. Such sequences may begin with 


\begin{tabular}{|c|l|l|}
\hline P1 & $\begin{array}{l}\text { A bridging leader who was responsible for managing the picket team in the Admiralty occupied site and facilitating } \\
\text { coordination between the leadership coalition and CSOs. }\end{array}$ & 21 August 2015 \\
\hline P2 & A core member of the leadership coalition who participated in the decision-making process. & 7 September 2015 \\
\hline P3 & $\begin{array}{l}\text { A core member of the leadership coalition who participated in the decision-making process and helped design the } \\
\text { movement campaigns. }\end{array}$ & 9 September 2015 \\
\hline P4 & $\begin{array}{l}\text { A bridging leader who was responsible for undertaking logistics support in the Admiralty occupied site and operating } \\
\text { the "Big Stage." }\end{array}$ & 10 September 2015 \\
\hline P5 & $\begin{array}{l}\text { A bridging leader who was responsible for organizing helpers, undertaking logistics support in the Admiralty occupied } \\
\text { site, and facilitating coordination between the leadership coalition and CSOs. }\end{array}$ & 10 September 2015 \\
\hline P6 & A core member of the leadership coalition who participated in the decision-making process. & 21 April 2016 \\
\hline
\end{tabular}

Note: We conducted interviews with the first five informants (P1 to P5) on campus at The Chinese University of Hong Kong. The interview with P6 was conducted on campus at The University of Hong Kong.

a rupture of routine practice, but "most ruptures are neutralized and reabsorbed into the pre-existing structures in one way or another" (Sewell 1996, p. 843). An occurrence becomes an event when it can significantly transform existing structures and processes by "disrupting, altering, or violating the taken-for-granted assumptions governing routine political and social relations" (McAdam and Sewell 2001, p. 110, emphasis in the original text) in a social movement. How political actors interpret and strategically respond to an antecedent event may influence later events (Lee and Chan 2011, p. 8). Hence, social movements can be seen as path-dependent, bounded sequences of events. This approach is helpful for analysing how particular contingent events (1) shape the underlying structure and path of collective action (Cheng 2016, p. 384) and (2) escalate and deescalate conflicts over time (McAdam and Sewell 2001, pp. 122-125).

We analyse contingent events with a focus on how the UM leadership interpreted them and made decisions about legitimating mechanisms at specific points in time. These events were identified for two reasons: first, our interviewees emphasised them as significant sources of legitimacy crises in the UM, and second, these events triggered the UM leadership's strategic responses and altered legitimating mechanisms. We continuously alternated between gathering and analysing the data (Claser and Strauss 1967, p. 102). This iterative research process allowed us to follow up on emerging themes in subsequent interviews and, thus, helped us constantly refine and reintegrate our theoretical and empirical inquiry.

\section{Legitimating mechanisms in the "Occupy Central Movement"}

We first explicate the legitimating mechanisms in the $\mathrm{OC}$ through which certain conceptions of legitimacy were formulated. The antecedents are discussed to situate the organisational constraints of later events. The $\mathrm{OC}$ was the precursor of the UM. It was a planned and centralised collective action prior to which the public had only a limited understanding of civil disobedience (Lee 2015, p. 394). Legitimacy is of particular importance for promoting contentious politics; specifically, the OCLP had to justify that "the tactic is just and right - from the perspective of those who are going to perform it" and to earn its "legitimacy in the eyes of others" (Biggs 2013, p. 409).

We might not use the term [legitimacy] directly, but this was indeed one of the considerations. From the very beginning, we [leaders of the OC] issued the letter of faith, providing a blueprint of how we would organise the movement; these are all grand principles [...]. Nonetheless, when it came to the details of the organisation of the occupation, we tried to make the decision-making process as transparent and as inclusive as possible; we did not want to be the sole decision-makers. Legitimacy was the chief concern of this move: an inclusive and transparent decision-making process tended to gain higher legitimacy. (4)

Benny Tai first introduced the concept of civil disobedience to the public in 2013 (Tai 2013). Later, he, together with Kin Man Chan and Yiu-Ming Chu, founded OCLP to support this idea and pertinent collective actions. OCLP emphasised the movement's strictly non-violent principle, as the purpose was to awaken the political consciousness of the public and to eventually generate public pressure for genuine democracy. The campaign inevitably had to address the city's longstanding culture of "peaceful" protest (Lee 2015, pp. 396-397). The three "deliberation days" (D-Days 1 , 2, and 3), two "civil referendums," and other campaigns served as "a transparent democratic procedure" to legitimise the collective action by enabling participants to discuss the movement's stance and strategies (Chan 2015, pp. 2-3). During the D-Days, OCLP invited core members of pandemocratic parties and CSOs to discuss the principles of the occupation. Using random sampling phone invitations, they also invited the general public to join the first D-Day. Only a small fraction of invited citizens (i.e., 95), however, attended. People who signed the "letter of intent," which was a promise to defer to OCLP's collective decisions, were allowed to vote for three out of more than ten movement proposals. To increase the public legitimacy of the movement, the three proposals were then incorporated into a public referendum to determine the final plan.

These legitimating mechanisms, however, offered limited degrees of inclusiveness. Though most information concerning purposes and strategies was transparent and the "civil referendums" provided opportunities for the public to endorse the movement, individuals had to agree with the three basic beliefs of OCLP in order to qualify as members, and during D-Days, the agenda-setting power was held exclusively by members. According to an interviewee from OCLP:

We were launching a movement. If you agree with it, you can come and join, while if you disagree, you can remain outside. No one forced anybody to join it. ${ }^{(5)}$

4. Interview with $P 6,21$ April 2016

5. Interview with $P 6,21$ April 2016. 
OCLP expected to launch the occupation movement in Central, the major business area, on 1 October 2014, and all participants were required to obey the Manual of Disobedience (OCLP 2014). The occupation was expected to last only a few days before moving on to the stage of peaceful and voluntary arrests. In the original plan, OCLP was the only leader, and the CSOs and student organisations were expected to play subsidiary roles. Though a coordination committee did exist, OCLP held exclusive decision-making power. ${ }^{(6)} \mathrm{A}$ top-down hierarchy was formed to reduce potential inter-organisation conflicts.

At this stage, D-Days and civil referendums were considered consensual building and democratic legitimation approaches. Through the deliberations, the OCLP hoped to acquire consensus and legitimacy among members, and through the civil referendums, it aspired to gain public support without giving non-members agenda-setting power. The top-down organisational structure was justified by its functional necessity in sustaining and coordinating the agreed-upon plan.

\section{Legitimacy crises and legitimating mechanisms in the Umbrella Movement}

As one interviewee stated, "The occurrence of the UM did not follow the script planned by OCLP." (7) Instead, following a more proactive imagination of civil disobedience (Chan 2015; Wong 2015), the student organisations stormed Civic Square in Admiralty on 26 September 2014. This represented an unplanned event in the OC's script, and it compelled the three OCLP leaders to launch the OC unexpectedly on 28 September (Cai 2017, pp. 4748). The protest swiftly transformed into a large-scale occupation in three locations: Admiralty, Mongkok, and Causeway Bay.

This unprecedented development altered the understanding of the movement's leadership. Though OCLP was originally perceived to be the sole legitimate leader, according to surveys conducted in the occupied sites in October, most participants were not mobilised by OCLP (Cheng and Chan 2017, pp. 225-229; Chan and Lee 2014). An on-site survey conducted by Cheng and Chan (2017) showed that only $17.7 \%$ of participants viewed OCLP as a legitimate leader, whereas $56.5 \%$ regarded the HKFS to be a legitimate leader (Cheng and Chan 2017, p. 225). ${ }^{(8)}$ The changes in the movement's implementation and timeline had created uncertainties and delegitimised OCLP's authority.

The remaining sections explore how the ways in which UM leadership articulated different legitimacy claims over various events revealed potential disruptions to participants' beliefs in the movement's claim to legitimacy during each phase.

\section{Legitimation mechanism 1: The "Five-Party Platform"}

The de-legitimisation of OCLP's leadership began when it declared that it would launch the OC campaign on 28 September. Many protesters fiercely criticised OCLP as "hijacking" the student strike, and some protesters even demanded that the leadership clarify that the student occupation was not part of the OC campaign. ${ }^{(9)}$ Some citizens left Civic Square to protest OCLP. This bottom-up challenge to OCLP leadership's legitimacy was unexpected, since OCLP leaders saw the early announcement of the OC campaign as a way of formally activating resources in support of the students' action, rather than as an attempt to take it over. In response to this crisis, members of the HKFS, who were responsible for speaking at the "Big Stage," (10) at- tempted to re-consolidate protesters by shifting the focus to the movement's values and visions. (11) OCLP eventually gave up its sole leadership, transitioning to an assistant role in which it "managed the occupied sites and offered suggestions to the students' decision-making." (12)

These unexpected events shifted the movement's leadership from OCLP to the HKFS and Scholarism. The outcomes were conditioned by the antecedent events (Cheng 2016). Because of the OC campaign, OCLP was still responsible for the mobilisation of human and financial resources. Some members of CSOs and volunteers still recognised OCLP as the primary legitimate leader. Hence, student leaders had to account for OCLP's voice in their decision-making processes. The increasing involvement of CSOs and pan-democratic parties since the second week of the movement had further complicated the situation. Both the HKFS and OCLP recognised the need to establish a legitimate decision-making mechanism to address the issues of representativeness, cooperation, and inter-group conflicts in a long-term occupation. Together, the HKFS, Scholarism, OCLP, CSOs, and pan-democracy political parties ${ }^{(13)}$ formed the "Five-Party Platform" (hereafter "the Platform") in October:

In the first few days, we [OCLP, CSOs, and pan-democracy political parties] made the best effort to accommodate students' decisions. However, oftentimes, student representatives had to go back and discuss with their standing committee members what we all had agreed on. Sometimes, due to the disagreement of these committee members, we had to overthrow the previous mutual agreement and re-launch the discussion again. This created a huge problem in our decision-making process [...]. [H]owever, starting from the second week of the movement, most CSOs had already entered the occupation, and pan-democratic political parties and legislators had also joined the Platform. Students [could] no longer be the sole decisionmaker in the movement. We had to come up with a platform to coordinate decision-making among different parties. (14)

The Platform was designed to facilitate collaboration among organisations, with the hope that improved communication would give their decisions greater legitimacy. In theory, the Platform was expected to help legitimise important decisions among major groups and supporters; however, it failed to function effectively as a decision-making mechanism. First, the Platform had no binding power, and groups were not forced to obey its decisions or agreements. (15) Unlike supra-organisations, such as the "federations" and "alliances" discussed by Zald and McCarthy (1980, pp. 14-15), the Platform did not require political actors to give up their discretionary rights; neither did it attribute power to any one actor. Instead, the various

\footnotetext{
6. Interview with P1, 21 August 2015.

7. Interview with P6, 21 April 2016.

8. In addition to OCLP and the HKFS, $29 \%$ of survey respondents viewed another student organisation, Scholarism, to be a legitimate leader, and 34.7\% considered the movement to be leaderless.

9. "Students Accuse Occupy Central of Hijacking Their Protest," South China Morning Post, 29 September 2014.

10. The "Big Stage" was a tall stage in the Admiralty occupation site that leaders used to disseminate messages to protestors.

11. Interviews with $\mathrm{P} 3$ and $\mathrm{P} 4,9$ and 10 September 2015.

12. Interview with $P 6,21$ April 2016.

13. Hereafter, we call the five groups the "leadership coalition."

14. Interview with $\mathrm{P6}, 21$ April 2016

15. Interviews with P1 and P2, 21 August and 7 September 2015, and with P6, 21 April 2016.
} 
Date

\begin{tabular}{|c|l|}
\hline 24 October 2014 & $\begin{array}{l}\text { The "Five-Party Platform" announced it would hold "occupied area voting" on } 26 \text { October to let UM supporters express their views } \\
\text { concerning the two proposals made by the government. }\end{array}$ \\
\hline 25 October 2014 & $\begin{array}{l}\text { The "Five-Party Platform" changed the wording of the two motions to be more progressive, and expanded the voting to include all } \\
\text { Admiralty, Mongkok, and Causeway Bay occupied areas. They also extended the voting period to } 27 \text { October. } \\
\text { - Voter requirement:Voters must confirm that they understand the contents of the two motions and support the Umbrella } \\
\text { Movement. }\end{array}$ \\
\hline 26 October 2014 & The "Five-Party Platform" announced the cancellation of the "occupied area voting." \\
\hline
\end{tabular}

Source: Authors' summary of news coverage in Apple Daily and Ming Pao and OCLP's website.

participating organisations viewed the Platform merely as a mechanism for coordinating logistics support and informing other organisations of their own decisions, largely overlooking the Platform's intended consensus-building and deliberative functions. ${ }^{(16)}$

Secondly, the Platform failed to facilitate mutual trust. ${ }^{(17)}$ Organisations had different imaginations of the constituencies, and these differences translated into disagreements over the most effective means of achieving the movement's goals. OCLP viewed protestors and the public as equally important constituencies; thus, it insisted on a principle of strict non-violence as a necessary condition to avoid public antipathy to the movement. Pandemocratic parties shared the same conception concerning the movement's constituencies, but believed that long-term occupation would unavoidably cause public antipathy; therefore, they argued that the movement should transition into other forms of "uncooperative movements." (18) They attempted to balance both public and participant legitimacy. In contrast, HKFS and Scholarism had more proactive imaginations of the movement. As we will discuss with respect to "occupied area voting," the students' conception of the constituencies leaned heavily towards the participants. In a platform of binding decision mechanisms, groups may have greater incentives to convince and negotiate with the opposite side; however, in the absence of such a mechanism, the Platform became merely a place for exposing differences. The tension began to intensify in late October, when opinion polls indicated declining general support for the UM (Lee 2016, p. 600).

Thirdly, the HKFS' internal "universal consensus" structure posed significant difficulties. The HKFS was a student organisation formed by the student unions of eight tertiary education institutions. According to its own rules, the organisation's decisions required a consensus of all member student unions; hence, its representatives in the Platform were not allowed to reach final decisions on behalf of the organisation without discussing these decisions with the other groups.

Since the Platform offered protesters no direct channels of participation, the protestors had to rely on their supported organisations to express their concerns. However, these organisations generally had no formal mechanisms for collecting supporters' opinions.

\section{Legitimating mechanism 2: Occupied area voting}

How can we legitimise our decisions in the occupation sites? [...] Even the "Five-Party Platform" had insufficient inclusiveness and legitimacy... Then, we came to the thought that a referendum might be the best solution. That is, all the participants can come back to the occupation sites and actually vote for a decision that they do indeed favour $[. .$.$] The referendum was designed to solve the problem$ of legitimacy. ${ }^{(19)}$
"Occupied area voting" is considered to be another contingent event that triggered a legitimacy crisis in the UM. This legitimating mechanism was intended to be a democratic procedure to empower the pro-democratic public and the movement's participants. Alex Chow made clear that the rationale behind the voting was to gain public endorsement of the occupation. ${ }^{(20)}$ The leadership coalition attempted to claim legitimacy by turning the movement participants and the public into decision-makers.

On 24 October 2014, the leadership coalition announced that it would hold the vote at the occupied Admiralty site on 26 October (see Table 2). Protesters, however, disagreed with the motions and the agenda-setting. They denounced the "Admiralty-orientated" voting as isolating the other two sites, and they also worried that anti-UM groups might hijack the movement, since no arrangement could effectively distinguish real participants from non-participants. For protesters, the vote was only a way to provide the leadership with legitimate excuses to end the movement. In response to these challenges, the leadership coalition revised the wording of the motions, expanded the voting to include all occupied sites, extended the voting period, and promised that the voting was not intended to end the UM. The revisions still failed to satisfy protestors. On 26 October, the Platform decided to cancel the vote.

The negotiations regarding occupied area voting represented one of the major conflicts between OCLP and the student organisations. As mentioned by an interviewee from OCLP, initially, all parties in the Platform reached a consensus concerning the need for the vote; however, soon after the vote's announcement, representatives from the HKFS claimed that the vote was not approved by their members. (21) OCLP and the pan-democracy parties saw a "withdrawal mechanism as a necessity because of the declining public sympathy to the movement," (22) while the HKFS wanted an enduring occupation, which they considered to be the desire of the participants. ${ }^{(23)}$ The conflict could be understood as follows: OCLP had a more inclusive view of "the constituency," suggesting that all citizens who supported the movement could cast a vote to decide the movement's future, whereas the HKFS valued movement participants' opinions more than the opinions of the public. This difference in opinion reflects two prominent questions that face all

16. "[Hou yusan yantaohui] Huang Zhifeng: Xu jiantao ruhe naru bentupai ji suren yijian" ([Post-umbrella movement seminar] Joshua Wong: We need to review how to take the views of localists and ordinary people into consideration), Independent Media, 3 September 2015, http://www.inmediahk.net/node/1037170 (accessed on 25 May 2017).

17. Interviews with P1 and P2, 21 August and 7 September 2015, and with P6, 21 April 2016

18. Interview with P6, 21 April 2016.

19. Interview with P6, 21 April 2016.

20. "Zhou Yongkang:Weilai bixu quangang toupiao" (Alex Chow: Hong Kong people will need to vote for the future), Ming Pao, 25 October 2014

21. Interview with $P 6,21$ April 2016.

22. Interview with $\mathrm{P6}, 21$ April 2016.

23. Interviews with $P 2$ and $P 3,7$ and 9 September 2015. 
Date

\begin{tabular}{|c|l|}
\hline 8 November 2014 & A protester claimed that the "Big Stage" (including the chief of picket, Kwok) forbade him from expressing his view publicly. \\
\hline 9 November 2014 & The "Big Stage" in Admiralty was opened for protesters to express their views publicly. \\
\hline 18 November 2014 & $\begin{array}{l}\text { A group of protesters organized a more radical protest to occupy the Legco building; however, some of them claimed the "Big Stage" } \\
\text { did not allow them to do so. }\end{array}$ \\
\hline 21 November 2014 & About one hundred protesters denounced the student leaders and OCLP, and called for disbanding the pickets. \\
\hline 24 November 2014 & Some protesters criticized the pickets in Admiralty. \\
\hline 30 November 2014 & HKFS organized a more radical protest as an attempt to occupy the Central Government Complex. \\
\hline 1 December 2014 & $\begin{array}{l}\text { Kam-mun Cheng asked the HKFS and Scholarism to conduct an open dialogue with him. The staff of the "Big Stage" sought to stop his } \\
\text { speech, and this led to conflicts among protesters. }\end{array}$ \\
\hline
\end{tabular}

Source: Authors' summary of news coverage in Apple Daily and Scholarism's Facebook page.

large-scale social movements: Who are the people? Whose voice should count? The primary divide between the two groups stemmed from their respective views on the limits of the leaders' authority. A core member of OCLP said:

Those [decision-makers] who oppose the referendum refuse to delegate the power of decision back to the participants. A referendum was unavoidably a way of giving back the decision-making power to the participants. If there were a democratic voting procedure, every participant would have a right to decide upon whether the occupation should end or not. I believe, from the perspective of the participants, it was not up to us, as main organisers of the movement, to make such [an] important decision. It was reasonable for them to question our legitimacy to make such a huge decision. (24)

Some HKFS members, in contrast, considered the voting to be an ineffective withdrawal mechanism and believed that solidarity among participants was more important than democratic and public legitimacy:

Assuming the result of the voting was that the majority of people had voted to leave, what if some of the participants were unwilling to comply with the result and decided to stay in the occupation sites? Of course, those who voted to leave could definitely leave, but who were going to take care of those who decided to remain? Sometimes, a democratic procedure might not be the best solution to a controversy. ${ }^{(25)}$

The event revealed that movement leaders were significantly constrained by bottom-up legitimacy challenges. An important factor that led OCLP to propose the voting was the inability of the leadership coalition to solve the already growing legitimacy concerns raised by participants. The fierce debates regarding the duration and legitimacy of the occupation had also resulted in a damaging split within the leadership coalition. This legitimacy crisis affected not only the leader-participant relationship, but also the leader-leader relationship.

\section{Legitimating mechanism 3: Opening the "Big Stage" and on-site mini-forums}

Despite the unsuccessful pursuit of direct democratic legitimacy, the leadership coalition realised that alternative strategies were needed to soften the protesters' anger. To this end, they opened the "Big Stage" and organised on-site mini-forum discussions in each of the occupied sites. Table 3 lists the major occurrences surrounding the protesters' challenges to the "Big Stage." Mongkok protesters ridiculed the legitimacy of the UM's leadership with the slogan "You [the leaders] don't represent me." Though it was commonly understood that protesters in Admiralty adhered more to the leadership, an interviewee from the picket team informed us that even there, the authority of the pickets had been increasingly challenged by protesters since October. ${ }^{(26)}$ OCLP and the HKFS repeatedly endeavoured to justify the picket team by its functional necessity; nonetheless, the team's collapsed legitimacy reached a breaking point on 8 November, when Jack Lee (2014), a protester and an HKU student, proclaimed that the pickets forbade him from speaking on the "Big Stage" because he might "threaten the leadership" by stating his belief that violent resistance was necessary to force the political authority to make concessions. Though Joshua Wong soon clarified that leaders welcomed transparent dialogue, by that point, the indignation surrounding the "Big Stage" was deeply rooted in the various communities of protesters.

The 8 November event created ruptures in the relatively top-down leadership structure, forcing the leadership coalition to develop a strategic response to the disgruntled protesters. Despite the disagreements on strategy, all members in the leadership coalition agreed on the principle of non-violence. Given the impossibility of directly satisfying radical protesters' demands, the leadership coalition decided to open the "Big Stage" for protesters to publicly express their views:

You have to provide an opportunity for them to release their emotions, since we had observed that protestors had already questioned the legitimacy of the leadership. Some of them might have problems with the legitimacy of the leadership, but their main dissatisfaction was due to the fact that there was no platform for them to publicly express their opinions and vent their anger. Opening the "Big Stage" can be an effective way to resolve such dissatisfaction. If we did not do so, and their anger cannot be mitigated, eventually they would completely overthrow the leadership. Therefore, rendering such a platform for indignant protestors was the best way to maintain the leadership. (27)

\footnotetext{
24. Interview with P6, 21 April 2016; emphasis added.

25. Interview with $\mathrm{P4}, 10$ September 2015.

26. Interview with P1, 21 August 2015

27. Interview with P1, 21 August 2015
} 
Date

Occurrence

\begin{tabular}{|c|l|}
\hline 25 October 2014 & The HKFS proposed asking five Legco members to resign in order to initiate the "Five-Districts Referendum." \\
\hline 31 October 2014 & $\begin{array}{l}\text { The "Five-Party Platform" put into discussions whether the referendum was a proper way to determine the future orientation of the } \\
\text { UM. }\end{array}$ \\
\hline 3 November 2014 & Joshua Wong wrote an article calling for the referendum. \\
\hline 6 November 2014 & $\begin{array}{l}\text { The Democratic Party and the Civic Party expressed concern about the potential costs and effectiveness of } \\
\text { "Five-Districts Referendum." }\end{array}$ \\
\hline
\end{tabular}

Source: Authors' summary of news coverage in Apple Daily and Ming Pao.

Opening the "Big Stage" created a channel through which protesters could relieve their anger towards the movement's leadership, and many protesters believed that through this channel, the leaders would receive and consider their opinions. However, opening the "Big Stage" also created opportunities for radicals to diffuse their animosity towards the leadership coalition. One such event occurred on 1 December when Kam-mun Cheng, a key figure within the radical protesters' community, used the "Big Stage" to excoriate the HKFS's decision to storm the Central Government Complex. For the radicals, the outcome of the movement was a vital factor in deciding the extent to which the leadership coalition could represent them. Consequently, the failure associated with storming the Central Government Complex deepened the tensions between the leadership coalition and the radicals.

Beginning in mid-October, the HKFS and OCLP also organised "mini-forum discussions" in all occupied sites. The chief purpose of these discussions was to show that the movement was not "leaderless":

The three leaders of OCLP must stay in the occupation sites [...]. They had to be seen by the participants, just like Alex Chow and Lester Shum [leaders of the HKFS] must be seen in the Mongkok site [...]. Since mid-October, the HKFS had established a station to demonstrate that they were in the occupation site. (28)

The leadership coalition sought to use this presence of symbolic leaders to connect the leadership with the protesters and to enable protesters to express their views and anger directly to the leaders. However, although the mini-forums did offer another source of information input, the leadership did not take this new input seriously. A number of interviewees claimed that the leadership already understood the protesters' viewpoints well; therefore, it was unnecessary to build a bridging mechanism to include participants in the decision-making process. $\left.{ }^{29}\right)$

\section{Legitimating mechanism 4: Legco members' resignation and referendum}

Following the announcement of on-site occupied area voting on $24 \mathrm{OC}-$ tober, the HKFS offered a counter-proposal on 25 October, calling for a de facto referendum through the resignation of the pan-democratic legislative councillors (see Table 4). The student organisations' push for this mechanism, which was intended to increase public legitimacy, was triggered by the failure of the occupied area voting initiative. Poll findings and pertinent news reports from late October onwards indicated that the majority of citizens were in favour of a UM retreat (Lee 2016, pp. 599-602). Later, in early November, Alex Chow and Joshua Wong realised and explicitly stated that mainstream public support was crucial for the movement's continuation
(Wong 2014). ${ }^{(30)}$ According to Hong Kong law, the resignation of a legislative councillor triggers a re-election in the councillor's district. A "referendum" is triggered when at least one pan-democratic legislator from all five electoral districts resigns from his position. Since every citizen would have known the rationale behind the councillors' resignations, the re-election of pan-democratic candidates could be seen as an indirect authorisation of the movement and the direction of its leadership.

By contrast, the major concern of the OCLP and the pan-democratic parties was whether the referendum could function as an effective withdrawal mechanism. Pan-democratic parties, such as the Democratic Party and the Civil Party, were worried about the potential costs of the referendum: specifically, if they failed to be re-elected, the pro-establishment would have enough votes to pass the electoral reform package. Therefore, they vetoed the proposal. In the interview with $\mathrm{P} 2$, we were told that Albert Ho had agreed to resign during the UM; however, since the student leaders did not agree to use the referendum to end the movement, the proposal was finally turned down. ${ }^{(31)}$

\section{Conclusion}

The article has shown that (1) legitimacy is not a settled issue, even in an apparently voluntary movement, and (2) legitimacy crises can significantly affect group coordination and leader-level decisions. From the above four legitimating mechanisms, we observe a process of "forced democratisation." When protestors begin to articulate alternative visions of a movement, they demand responses from their leaders. Leaders must then search for potential claims of legitimacy to resolve these bottom-up pressures. Oftentimes, the solution involves a more transparent and inclusive decision-making process. In the case of the UM, when the leadership encountered bottom-up pressures, the movement's Weberian charismatic and functional approach gradually developed into a consensual-oriented approach and then - when this change failed to diminish the pressures - a democratic approach.

From the very beginning, the leaders of OCLP had anticipated this problem and had made OCLP extremely democratic by employing both consensual and democratic approaches at almost every stage of the intragroup decision-making process. However, the sudden transformation of the OC campaign into the UM interrupted this mechanism. When the movement began to include participants who were not loyal adherents of the OC's plan, OCLP leaders faced bottom-up pressure to re-legitimise their leadership. They first

28. Interview with $\mathrm{P} 2,7$ September 2015 .

29. Interviews with P2 and P4, 7 and 9 September 2015, and with P6, 21 April 2016.

30. "Zhou Yongkang: Bian xiang gong tou she qu zhan kai zheng shi min zhi chi" (Alex Chow: Getting support from Hong Kong citizens through launching of De Facto Referendum), Ming Pao, 2 November 2014.

31. Interview with $\mathrm{P} 2,7$ September 2015 
attempted to create a Platform encompassing all major leaders. By employing Weberian charismatic (i.e., the purity of student leaders), functional, and consensual approaches, they hoped to incorporate both political capital and the perspectives of student organisations, CSOs, and pan-democratic parties to legitimise their leadership. However, the internal structural constraints of the HKFS and the distrustful relationships among the parties ultimately made the Platform ineffective. Hence, the OCLP's claim to legitimacy was unsuccessful because its first legitimating mechanism failed to achieve both functional and consensual requirements.

With growing bottom-up pressure and increasingly ineffective functional and consensual approaches, OCLP and the HKFS decided to pursue a more radical strategy: the democratic approach of "on-site voting." The two purposes of this initiative were to ensure representativeness and to consolidate the legitimacy of the UM's leadership. Unfortunately, disagreements over who counted as "the people" and the weighing of solidarity and legitimacy ultimately nullified the effort. The failure to establish a direct democratic mechanism caused rising indignation among radical protestors, who began to target the movement's two symbols of power: the picket team and the "Big Stage." Leaders were compelled to "democratise" these symbols in an effort to alleviate the protesters' anger and cloak the decision-making process in a façade of inclusivity. However, the decision to open the "Big Stage" backfired, as the stage was converted into an instrument for radical communities to spread anti-leadership messages that further impaired their legitimacy. The leadership's final attempt to achieve legitimacy by forcing a real referendum through the resignation of pan-democratic legislators also failed because leaders were split into two sides with completely conflicting visions concerning the objective of the referendum.

Over the course of the UM, attention shifted from the strike against the government to internal conflicts between participants and leaders concerning the issue of legitimacy. Bottom-up pressures not only compelled leaders to adopt new strategies regarding the management and organisation of the movement, but also exposed their differences, undercutting the very basis of effective coordination. Although all three approaches (Weberian charismatic, functional, and consensual) were put into practice, the legitimacy challenges never ended. The two failures to establish genuine democratic approach (on-site and beyond-site voting) had fatal consequences for crossoccupied site coordination and leader cooperation. The case of the UM shows that sharing a commitment to the same injustices does not resolve disagreements over strategies or direction. Furthermore, in an inclusive large-scale movement, effective and legitimate leadership cannot be grounded in non-democratic approaches. In sum, this analysis shows that there is a need to seriously reflect on possible and feasible methods of democracy in social movements.

I Chi Kwok is a PhD student in political theory at the University of Toronto.

Department of Political Science, University of Toronto, Sidney Smith Hall, Room 3018, 100 St. George Street, Toronto, ON M5S 3G3, Canada (chi.kwok@mail.utoronto.ca).

INgai Keung Chan is a PhD student in communication at Cornell University.

Department of Communication, Cornell University, 454 Mann

Library Building, Ithaca, NY 14853, USA (nc478@cornell.edu).

\section{REFERENCES}

AMINZADE, Ronald, Jack GOLDSTONE, and Elizabeth PERRY. 2001. "Leadership Dynamics and Dynamics of Contention." In Ronald Aminzade, Jack Goldstone, Doug McAdam, Elizabeth Perry, William Sewell, Sidney Tarrow, and Charles Tilly (eds), Silence and Voice in the Study of Contentious Politics. New York: Cambridge University Press. 126-54.

ANDREWS, Kenneth T., Kraig BEYERLEIN, and Tuneka TUCKER FARNUM. 2015. "The Legitimacy of Protest: Explaining White Southerners' Attitudes Toward the Civil Rights Movement." Social Forces 94: 1021-44.

CAl, Yongshun. 2017. The Occupy Movement in Hong Kong: Sustaining Decentralized Protest. New York: Routledge.

CHAN, Joseph Man, and Francis Lap-fung LEE. 2014. "Zhanling yundong xinzu zhi xingtai chutan" (Preliminary Research on the New Organizational Forms of Occupy Movement). Ming Pao, 9 November.

CHAN, Kin-man. 2015. "Occupying Hong Kong: How Deliberation, Referendum and Civil Disobedience Played Out in the Umbrella Movement." International Journal on Human Rights 12(21): 1-7.

CHENG, Edmund W. 2016. "Street Politics in a Hybrid Regime: The Diffusion of Political Activism in Post-colonial Hong Kong." The China Quarterly 226: 383406.

CHENG, Edmund W., and Wai-Yin CHAN. 2017. "Explaining Spontaneous Occupation: Antecedents and Contingencies in the Making of the Umbrella Movement." Social Movement Studies 16: 222-39.

DAVIS, Michael C. 2015. "Hong Kong's Umbrella Movement: Beijing's Broken Promises." Journal of Democracy 26: 101-10.

DINH, Jessica, Robert LORD, William GARDNER, Jeremy MEUSER, Robert LIDEN, and Jinyu HU. 2014. "Leadership Theory and Research in the New Millennium: Current Theoretical Trends and Changing Perspectives." The Leadership Quarterly 25: $36-62$.

EARL, Jennifer. 2007. "Leading Tasks in a Leaderless Movement: The Case of Strategic Voting." American Behavioral Scientist 50: 1327-49.

HAUNSS, Sebastian. 2007. "Challenging Legitimacy: Repertoires of Contention, Political Claims Making, and Collective Action Frames." In Achim Hurrelmann, Steffen Schneider, and Jens Steffek (eds), Legitimacy in an Age of Global Politics. Houndmills: Palgrave Macmillan. 156-72.

GAN, Wendy. 2017. "Puckish Protesting in the Umbrella Movement." International Journal of Cultural Studies 20: 162-76.

GANZ, Marshall. 2010. "Leading Change: Leadership, Organization, and Social Movements." In Nitin Nohria and Rakesh Khurana (eds), Handbook of Leadership Theory and Practice. Boston: Harvard Business School Publishing Corporation. 141.

GLASER, Barney G., and Anselm L. STRAUSS. 1967. The Discovery of Grounded Theory: Strategies for Qualitative Research. Chicago: Aldine Publishing Co.

HUI, Po-Keung, and Kin-Chi LAU. 2015. "'Living in Truth' versus Realpolitik: Limitations and Potentials of the Umbrella Movement." Inter-Asia Cultural Studies 16: 348-66.

KALDOR, Mary. 2003. "The Idea of Global Civil Society." International Affairs 79: 583-93.

LAGERKVIST, John, and Tim RÜHLIG. 2016. "The Mobilization of Memory and Tradition: Hong Kong's Umbrella Movement and Beijing's 1989 Tiananmen Movement." Contemporary Chinese Political Economy and Strategic Relations 2: $735-74$.

LEE, Alice Y. L., and Ka Wan TING. 2015. "Media and Information Praxis of Young Activists in the Umbrella Movement." Chinese Journal of Communication 8: 376-92.

LEE, Francis Lap-fung. 2015. "Social Movement as Civic Education. Communication Activities and the Understanding of the Civil Disobedience in the Umbrella Movement." Chinese Journal of Communication 8: 393-411. 
LEE, Francis Lap-fung. 2016. "Opinion Polling and Construction of Public Opinion in Newspaper Discourses during the Umbrella Movement." Journal of Language and Politics 15: 599-604.

LEE, Francis Lap-fung, and Joseph Man CHAN. 2011. Media, Social Mobilization and Mass Protests in Post-colonial Hong Kong: The Power of a Critical Event. New York: Routledge.

LEE, Francis Lap-fung, and Joseph Man CHAN. 2016. "Digital Media Activities and Mode of Participation in a Protest Campaign: A Study of the Umbrella Movement." Information, Communication \& Society 19: 4-22.

LEE, Jack. 2014. "Ganji suoyou wei xianggang fuchu de ren, ye ganji Huang Zhifeng tongxue" (Thankful to Hong Kongers who contributed to Hong Kong; Thankful to Joshua Wong). VJ Media, 9 November. http://www.vjmedia.com.hk/articles/ 2014/11/09/90403/ (accessed on 25 May 2017).

LEE, Paul S. N., Clement Y. K. SO, and Louis LEUNG. 2015. "Social Media and Umbrella Movement: Insurgent Public Sphere in Formation." Chinese Journal of Communication 8: 356-75.

LIN, Zhongxuan. 2017. "Contextualized Transmedia Mobilization: Media Practices and Mobilizing Structures in the Umbrella Movement." International Journal of Communication 11: 48-71.

LIN, Zhongxuan, and Shih-Ding LIU. 2016. "Occupation as Prefiguration? The Emergence of a New Political Form in the Occupy Central Movement." Contemporary Chinese Political Economy and Strategic Relations 2: 775-94.

LUI, Tai-lok. 2015. "A Missing Page in the Grand Plan of 'One Country, Two Systems': Regional Integration and its Challenges to Post-1997 Hong Kong." Inter-Asia Cultural Studies 16: 396-409.

MANSBRIDGE, Jane. 2003. "Rethinking Representation." American Political Science Review 97: 515-28.

MAXWELL, Joseph. 2013. Qualitative Research Design: An Interactive Approach. $3^{\text {rd }}$ ed. Thousand Oaks: Sage.

MCADAM, Doug, and William H. Jr. SEWELL. 2001. "It's About Time:Temporality in the Study of Social Movements and Revolutions." In Ronald Aminzade, Jack Goldstone, Doug McAdam, Elizabeth Perry, William Sewell, Sidney Tarrow, and Charles Tilly (eds), Silence and Voice in the Study of Contentious Politics. New York: Cambridge University Press. 89-125.

MCADAM, Doug, Sidney TARROW, and Charles TILLY. 2001. Dynamics of Contention. Cambridge: Cambridge University Press.

MICHELS, Robert. 1962. Political Parties: A Sociological Study of the Oligarchical Tendencies of Modern Democracy. New York, Collier.

MORRIS, Aldon, and Suzanne STAGGENBORG. 2004. "Leadership in Social Movements." In David A. Snow, Sarah A. Soule, and Hanspeter Kriesi (eds), The Blackwell Companion to Social Movements. Oxford: Blackwell. 171-96.

PLATT, Gerald, and Stephen LILLEY. 1994. "Multiple Images of a Charismatic: Constructing Martin Luther King Jr.'s Leadership." In Gerald Platt and Chad Gordon (eds), Self, Collective Behavior and Society: Essays Honoring the Contributions of Ralph H. Turner. Bingley: Emerald Group Publishing. 55-74.

PORTA, Donatella della. 2009. "Consensus in Movements." In Donatella della Porta (ed), Democracy in Social Movements. Hampshire: Palgrave Macmillan. 73-99.

OCLP. 2014. "OCLP - Manual of Disobedience." http://oclp.hk/?route=occupy/ eng_detail\&eng_id=28 (accessed on 25 May 2017).

ORTMAN, Stephan. 2015. "The Umbrella Movement and Hong Kong's Protracted Democratization Process." Asian Affairs 46: 32-50.

RAO, Hayagreeva, Calvin MORRILL, and Mayer N. ZALD. 2000. "Power Plays: How Social Movements and Collective Action Create New Organizational Forms." Research in Organizational Behavior 22: 237-81.
ROBNETT, Belinda. 1996. "African-American Women in the Civil Rights Movement, 1954-1965: Gender, Leadership, and Micromobilization." American Journal of Sociology 101: 1661-93.

RÜHLIG, Tim. 2016. "Do You Hear the People Sing 'Lift Your Umbrella': Understanding Hong Kong's Pro-democratic Umbrella Movement through YouTube Music Videos." China Perspectives 2016(4): 59-68.

SEWELL, William H. Jr. 1996. "Historical Events as Transformations of Structures: Inventing Revolution at the Bastille." Theory and Society 25: 841-81.

SNOW, David, and Robert BENFORD. 1992. "Master Frames and Cycles of Protest." In Aldon Morris and Carol McClurg Mueller (eds), Frontiers in Social Movement Theory. New Haven:Yale University Press. 133-55.

SOULE, Sarah, and Brayden KING. 2008. "Competition and Resource Partitioning in Three Social Movement Industries." American Journal of Sociology 113: 15681610.

TANG, Gary. 2015. "Mobilization by Images: TV Screen and Mediated Instant Grievances in the Umbrella Movement." Chinese Journal of Communication 8: 338-55.

TAl, Benny. 2013. "Gongmin kangming de zuida shashangli wuqi" (The Most destructive weapon of civil disobedience). Hong Kong Economic Journal, 16 January.

TARROW, Sidney. 2011. Power in Movement: Social Movements and Contentious Politics. $3^{\text {rd }}$ ed. Cambridge: Cambridge University Press.

TILLY, Charles, and Sidney TARROW. 2015. Contentious Politics. Colorado: Paradigm. TOEPFL, Florian. 2017. "From Connective to Collective Action: Internet Elections as a Digital Tool to Centralize and Formalize Protest in Russia." Information, Communication \& Society. http://dx.doi.org/10.1080/1369118X.2017.1290127 (accessed on 25 May 2017).

TURNER, Stephen. 2008. "Blind Spot? Weber's Concept of Expertise and the Perplexing Case of China." In David Chalcraft, Fanon Howell, and Hector Vera (eds), Max Weber Matters: Interweaving Past and Present. Burlington: Ashgate. 121-134.

VEG, Sebastian. 2015. "Legalistic and Utopian: Hong Kong's Umbrella Movement." New Left Review, 92: 54-73.

VEG, Sebastian. 2016. "Creating a Textual Public Space: Slogans and Texts from Hong Kong's Umbrella Movement." The Journal of Asian Studies 75: 673-702.

WANG, Klavier Jie Ying. 2017. "Mobilizing Resources to the Square: Hong Kong's Anti-Moral and National Education Movement as Precursor to the Umbrella Movement." International Journal of Cultural Studies 20: 127-45.

WAPNER, Paul. 1995. "Politics Beyond the State: Environmental Activism and World Civic Politics." World Politics 47: 311-40.

WEBER, Max. 1968. Economy and Society. Berkeley: University of California Press. WILSON, James Q. 1974. Political Organizations. New Haven: Princeton University Press.

WONG, Joshua. 2014. "Weihe yusan yundong yao chuxian chao qu cizhi gongtou?" (Why is it necessary to have a De Facto Referendum?). Independent Media, 3 November. http://www.inmediahk.net/node/20141103a (accessed on 25 May 2017).

WONG, Joshua. 2015. "Scholarism on the March." New Left Review 92: 43-52.

ZALD, Mayer N., and John D. MCCARTHY. 1980. "Social Movement Industries: Cooperation and Conflict amongst Social Movement Organizations." In Louis Kriesberg (ed), Research in Social Movements, Conflict, and Change, vol. 3. Greenwich: JAl Press. 1-20.

ZALD, Mayer N., and Robert ASH. 1966. "Social Movement Organizations: Growth, Decay and Change." Social Forces 44: 327-41. 